\title{
Formation and biocorrosion behavior of Zr-Al-Co-Nb bulk metallic glasses
}

\author{
LU XuYang, HUANG Lu, PANG ShuJie* \& ZHANG Tao \\ Key Laboratory of Aerospace Materials and Performance (Ministry of Education), School of Materials Science and Engineering, Beihang \\ University, Beijing 100191, China
}

Received November 14, 2011; accepted December 13, 2011; published online March 8, 2012

\begin{abstract}
$\mathrm{Ni}$ - and $\mathrm{Cu}$-free $\mathrm{Zr}$-Al-Co-Nb glassy alloys with different $\mathrm{Nb}$ and $\mathrm{Co}$ contents were synthesized by melt spinning and copper mold casting. The effects of $\mathrm{Nb}$ addition to partially replace $\mathrm{Co}$ in the $\mathrm{Zr}_{55} \mathrm{Al}_{20} \mathrm{Co}_{25}$ glassy alloy on the glass-forming ability, thermal properties, in-vitro biocorrosion behavior and surface wettability of the metallic glasses were investigated. Although addition of $\mathrm{Nb}$ up to 5 at.\% slightly decreased the supercooled liquid region and the glass-forming ability (GFA), the alloys could be casted in a bulk glassy rod form with diameters up to $3 \mathrm{~mm}$. The Zr-Al-Co-Nb glassy alloys were spontaneously passivated with low passive current densities in phosphate buffered saline and Hanks' solution. Substitution of "toxic" Co by Nb is effective in improved the corrosion resistance of the $\mathrm{Zr}$-Al-Co glassy alloy. Water contact angle measurements showed that $\mathrm{Nb}$ addition increased the hydrophilicity of the glassy alloys, which may enhance cell adhesion of the alloys in biomedical applications.
\end{abstract}

Zr-based alloy, Nb, metallic glass, corrosion, biocompatibility

Citation: $\quad$ Lu X Y, Huang L, Pang S J, et al. Formation and biocorrosion behavior of Zr-Al-Co-Nb bulk metallic glasses. Chin Sci Bull, 2012, 57: 1723-1727, doi: $10.1007 / \mathrm{s} 11434-012-5027-0$

Because of the lack of long-range atomic order, Zr-based bulk metallic glasses (BMGs) exhibit superior strength, high elastic strain limits and fatigue endurance limits, relatively low Young's modulus, and excellent wear and corrosion resistance [1-5], which attracted attention in biomedical applications. However, toxic elements such as nickel and copper are often included in Zr-based metallic glasses to achieve high glass-forming ability (GFA), which are thought to impair cellular metabolism [6]. In recent years, many efforts have been made to remove these elements from Zr-based BMGs to further improve their biocompatibility. Major efforts have been made in removing Ni from the alloying elements, because $\mathrm{Ni}$ is a known allergen. Ni-free glass forming systems such as $\mathrm{Zr}-\mathrm{Al}-\mathrm{Cu}$ [7], $\mathrm{Zr}-\mathrm{Al}-\mathrm{Co}$ [8-11], Zr-Al-Co-Cu [12], Zr-Al-Fe-Cu [13], Zr-Cu-Pd$\mathrm{Al}-\mathrm{Nb}$ [14], Zr-(Cu, Ag)-Al [15], Zr-Al-Cu-Fe-(Ti/Nb) [16], and $\mathrm{Zr}-\mathrm{Al}-\mathrm{Co}-\mathrm{Ag}[17,18]$ have been developed. Among the

\footnotetext{
*Corresponding author (email: pangshujie@buaa.edu.cn)
}

Ni-free Zr-based BMGs, Zr-Al-Co BMGs are attractive because they are free from copper, which may result in high cytotoxicity if excessive release occurs during corrosion and is also an element of concern in biomaterials [19]. Based on the ternary $\mathrm{Zr}_{55} \mathrm{Al}_{20} \mathrm{Co}_{25}$ alloy with high GFA, quaternary $\mathrm{Zr}_{55} \mathrm{Al}_{20-x} \mathrm{Co}_{25} \mathrm{Nb}_{x}(x=2.5$ at.\% and 5 at.\%) metallic glasses have been developed, and addition of $\mathrm{Nb}$ were found to enhance their resistance to pitting corrosion in 3 mass\% $\mathrm{NaCl}$ solution [20]. From the viewpoint of biomedical engineering, $\mathrm{Nb}$ is recognized as a highly biocompatible element. In the quaternary $\mathrm{Zr}-\mathrm{Al}-\mathrm{Co}-\mathrm{Nb}$ alloys, Co is more cytotoxic than $\mathrm{Al}$, and excessive amounts of Co or prolonged exposure to Co may result in Co poisoning [21-23]. Therefore, rather than substitution of $\mathrm{Al}$ with $\mathrm{Nb}$ as in the previous study [20], substitution of Co with $\mathrm{Nb}$ could further improve the biocompatibility of the alloys. In consideration of potential medical applications, the GFA and in vitro biocorrosion behavior of $\mathrm{Zr}_{55} \mathrm{Al}_{20} \mathrm{Co}_{25-x} \mathrm{Nb}_{x}$ glassy alloys were investigated in the present work. Surface wettability of the 
$\mathrm{Zr}_{55} \mathrm{Al}_{20} \mathrm{Co}_{25-x} \mathrm{Nb}_{x}$ glassy alloys was also studied, which can be related to cell attachment/adhesion with relatively higher hydrophilicity enhancing cell adhesion [24,25]. The effects of substitution of $\mathrm{Co}$ with $\mathrm{Nb}$ on the formation and corrosion resistance of the $\mathrm{Zr}$-Al-Co glassy alloy are discussed.

\section{Experimental}

Master alloys with nominal compositions of $\mathrm{Zr}_{55} \mathrm{Al}_{20} \mathrm{Co}_{25-x^{-}}$ $\mathrm{Nb}_{x}(x=0,2.5$ at.\% and 5 at.\%) were prepared by arc melting mixtures of the pure metals in a Ti-gettered high-purity argon atmosphere. Ribbon samples (thickness $0.02 \mathrm{~mm}$, width 1 or $4 \mathrm{~mm}$ ) and cylindrical alloy rods with different diameters were prepared from crushed alloy ingots in an argon atmosphere by melt spinning and injection copper mold casting, respectively. The microstructures of the specimens were examined by $\mathrm{X}$-ray diffraction (XRD) with $\mathrm{Cu}-\mathrm{K} \alpha$ radiation. The thermal stability of the alloys was investigated by differential scanning calorimetry (DSC) at a heating rate of $0.33 \mathrm{~K} / \mathrm{s}$.

The electrochemical behaviors of the $\mathrm{Zr}-\mathrm{Al}-\mathrm{Co}-\mathrm{Nb}$ glassy alloys were characterized using ribbon samples of $1 \mathrm{~mm}$ wide in phosphate-buffered saline (PBS) and Hanks' balanced salt solution. Before the tests, the solutions were heated to $310 \mathrm{~K}$ in a water bath and aerated with 4 vol.\% $\mathrm{O}_{2} / \mathrm{N}_{2}$ gas mixture at a flow rate of $50 \mathrm{~mL} / \mathrm{min}$. Aeration was continued throughout the tests. The surface of each specimen was mechanically polished in cyclohexane with silicon carbide paper up to \# 2000 (average particle diameter $10 \mu \mathrm{m})$, degreased in acetone, cleaned in ethanol and distilled water, dried in air, and then exposed to air for about $24 \mathrm{~h}$ for good reproducibility. A three-electrode cell system consisting of a corrosion sample as the working electrode, a saturated calomel reference electrode (SCE, $E_{\mathrm{SCE}}=$ $0.242 \mathrm{~V}$ ), and a platinum counter electrode was adopted. Prior to potentiodynamic polarizations, the test samples were immersed in the electrolytes for $4000 \mathrm{~s}$ to allow open circuit potentials (OCPs) to reach steady state. Anodic potentiodynamic polarization tests were started at about $0.05 \mathrm{~V}$ below the OCPs at a potential sweep rate of $50 \mathrm{mV} / \mathrm{min}$.

For the characterization of the surface wettability of the glassy alloys, water contact angles were measured using the sessile drop technique at $298 \mathrm{~K}$ with 4-mm-wide ribbon samples. The surface of each ribbon sample was polished with silicon carbide paper up to \# 2000, cleaned in an ultrasonic cleaner with acetone, ethanol and distilled water, and then dried in air. Deionized water droplets (about $0.5 \mu \mathrm{L}$ ) were dropped carefully onto the surface. Measurements were performed at five different positions along each sample and the average contact angle was calculated.

\section{Results and discussion}

XRD patterns of the $\mathrm{Zr}_{55} \mathrm{Al}_{20} \mathrm{Co}_{25-x} \mathrm{Nb}_{x}$ (at.\%) alloy samples with different geometries are shown in Figure 1. The XRD patterns of the $\mathrm{Zr}_{55} \mathrm{Al}_{20} \mathrm{Co}_{25}$ alloys with diameters up to $5 \mathrm{~mm}$ show a broad peak at around $2 \theta=37^{\circ}$, which is characteristic of the amorphous structure. $\mathrm{Nb}$ addition negatively impact glass formation of the Zr-Al-Co alloy. Substitution of Co by $\mathrm{Nb}$ at 2.5 at.\% decreases the critical diameter for glass formation to $3 \mathrm{~mm}$. Crystallization peaks for $\mathrm{Zr}_{6} \mathrm{Al}_{2} \mathrm{Co}$ and $\mathrm{ZrCo}$ can be observed in the diffraction pattern of the $\phi$ $5 \mathrm{~mm}$ sample. When the $\mathrm{Nb}$ content is increased to 5 at.\%, the critical diameter of the $\mathrm{Zr}_{55} \mathrm{Al}_{20} \mathrm{Co}_{20} \mathrm{Nb}_{5}$ BMG decreases to $2 \mathrm{~mm}$. The XRD patterns of partially crystallized $\mathrm{Zr}$-Al$\mathrm{Co}-\mathrm{Nb}$ alloys indicate that $\mathrm{Nb}$ addition influences the GFA of the $\mathrm{Zr}$-Al-Co BMGs by enhancing formation of $\mathrm{Zr}_{6} \mathrm{Al}_{2} \mathrm{Co}$
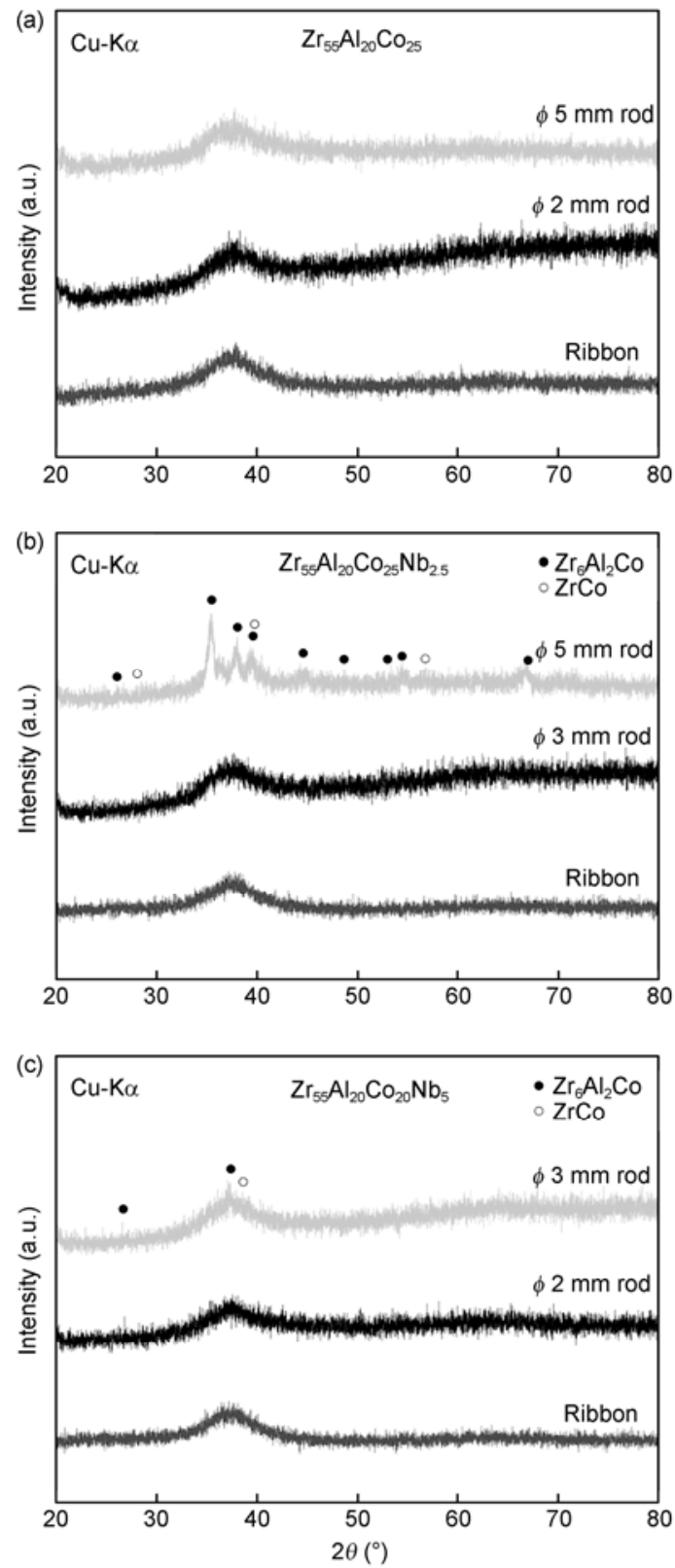

Figure $1 \mathrm{XRD}$ patterns of $\mathrm{Zr}_{55} \mathrm{Al}_{20} \mathrm{Co}_{25-x} \mathrm{Nb}_{x}(x=0,2.5$ at.\% and 5 at.\%) ribbon and rod samples. 
and $\mathrm{ZrCo}$ phases.

DSC curves of the $\mathrm{Zr}-\mathrm{Al}-\mathrm{Co}-\mathrm{Nb}$ alloy ribbons and rods with their critical diameters are shown in Figure 2, where $T_{\mathrm{g}}$ and $T_{\mathrm{x}}$ are glass transition temperature and onset temperature of crystallization, respectively. Upon heating, each of the samples exhibits a distinct glass transition followed by a wide supercooled liquid region $\left(\Delta T_{\mathrm{x}}=T_{\mathrm{x}}-T_{\mathrm{g}}\right)$ before crystallization. The values of $T_{\mathrm{g}}, T_{\mathrm{x}}$, and heat release of the crystallization for the rod samples are almost identical to those of the ribbon samples with the same compositions, which further confirms the glassy structure of the bulk alloys. With the increase in $\mathrm{Nb}$ content, $T_{\mathrm{g}}$ decreases from 746 to $728 \mathrm{~K}$, and $T_{\mathrm{x}}$ decreases from 821 to $790 \mathrm{~K}$, which causes a decrease in $\Delta T_{\mathrm{x}}$ from 75 to $62 \mathrm{~K}$. The decrease in $\Delta T_{\mathrm{x}}$ can be correlated with the decrease in the GFA of the alloys.

To simulate body fluid, PBS and Hank's solution were used in corrosion tests. The former is a simple solution with a similar $\mathrm{Cl}^{-}$concentration and $\mathrm{pH}$ value to body fluid, and the later is more complex, which additionally contains $\mathrm{Mg}^{2+}$, $\mathrm{Ca}^{2+}$, and glucose. Changes in the open circuit potential with immersion time for the $\mathrm{Zr}_{55} \mathrm{Al}_{20} \mathrm{Co}_{25-x} \mathrm{Nb}_{x}(x=0,2.5$ at.\% and 5 at.\%) glassy alloys in PBS and Hanks' solution are illustrated in Figure 3. During immersion, the potential of each alloy initially rises steeply and then slows down until reaches constant values, which are determined as OCPs. The OCP values of the alloys in both solutions increase with the increase in $\mathrm{Nb}$ content, indicating that $\mathrm{Nb}$ addition improved the stability of the surface films of the alloys.

Figure 4 shows the anodic polarization curves of the glassy alloys in PBS and Hanks' solution at $310 \mathrm{~K}$ with aeration of $\mathrm{O}_{2} / \mathrm{N}_{2}$ gas mixture at $50 \mathrm{~mL} / \mathrm{min}$. All alloys are spontaneously passivated with wide passive regions before pitting in both electrolytes, and their passive current densities are around $0.08 \mathrm{~A} / \mathrm{m}^{2}$. Figure 5 shows that the pitting potential of the $\mathrm{Zr}_{55} \mathrm{Al}_{20} \mathrm{Co}_{25-x} \mathrm{Nb}_{x}$ BMGs increases considerably with increasing $\mathrm{Nb}$ content. Therefore, partial substitution of $\mathrm{Co}$ by $\mathrm{Nb}$ effectively improves the corrosion resistance of the $\mathrm{Zr}_{55} \mathrm{Al}_{20} \mathrm{Co}_{25}$ BMG in the simulated body

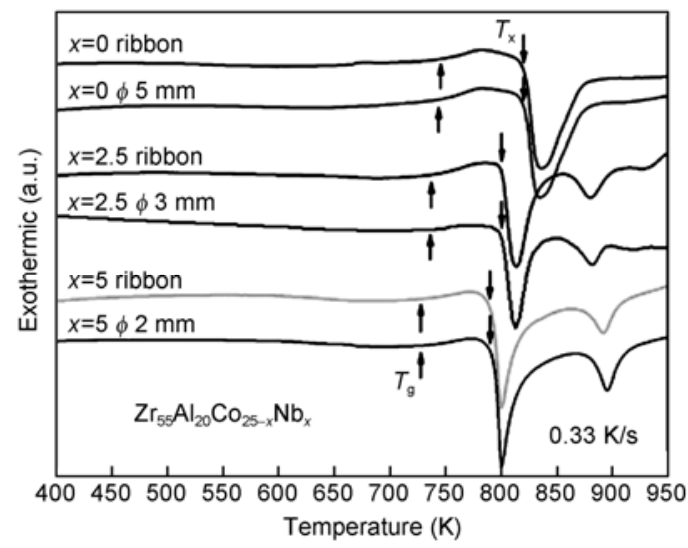

Figure 2 DSC curves of $\mathrm{Zr}_{55} \mathrm{Al}_{20} \mathrm{Co}_{25-x} \mathrm{Nb}_{x}(x=0,2.5$ at.\% and 5 at.\%) ribbon and rod samples.
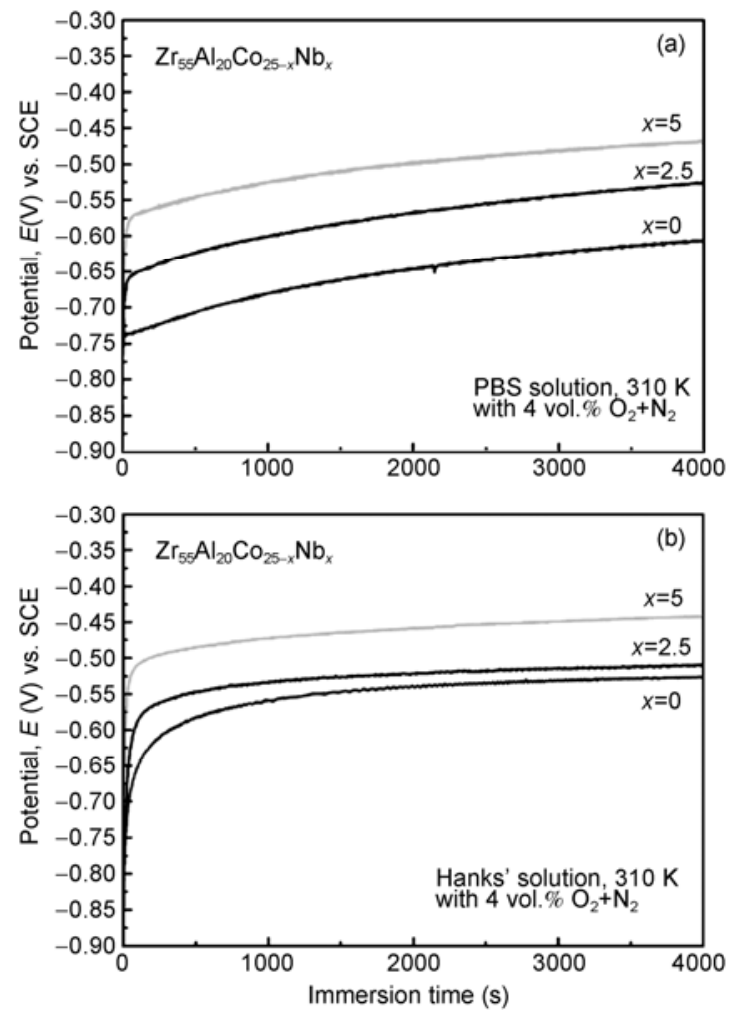

Figure 3 Changes in the open-circuit potential with immersion time for $\mathrm{Zr}_{55} \mathrm{Al}_{20} \mathrm{Co}_{25-x} \mathrm{Nb}_{x}(x=0,2.5$ at.\% and 5 at.\%) glassy alloys in PBS and Hanks' solution.
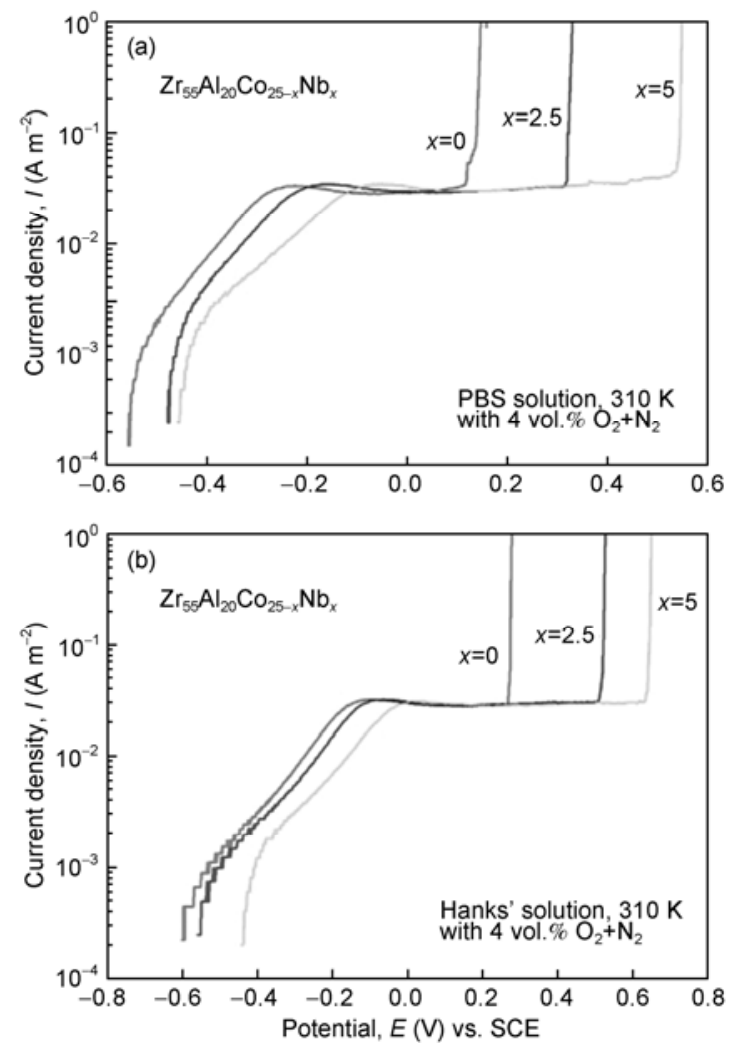

Figure 4 Anodic polarization curves of $\mathrm{Zr}_{55} \mathrm{Al}_{20} \mathrm{Co}_{25-x} \mathrm{Nb}_{x}(x=0,2.5$ at. $\%$ and 5 at.\%) glassy alloys in PBS and Hanks' solution. 

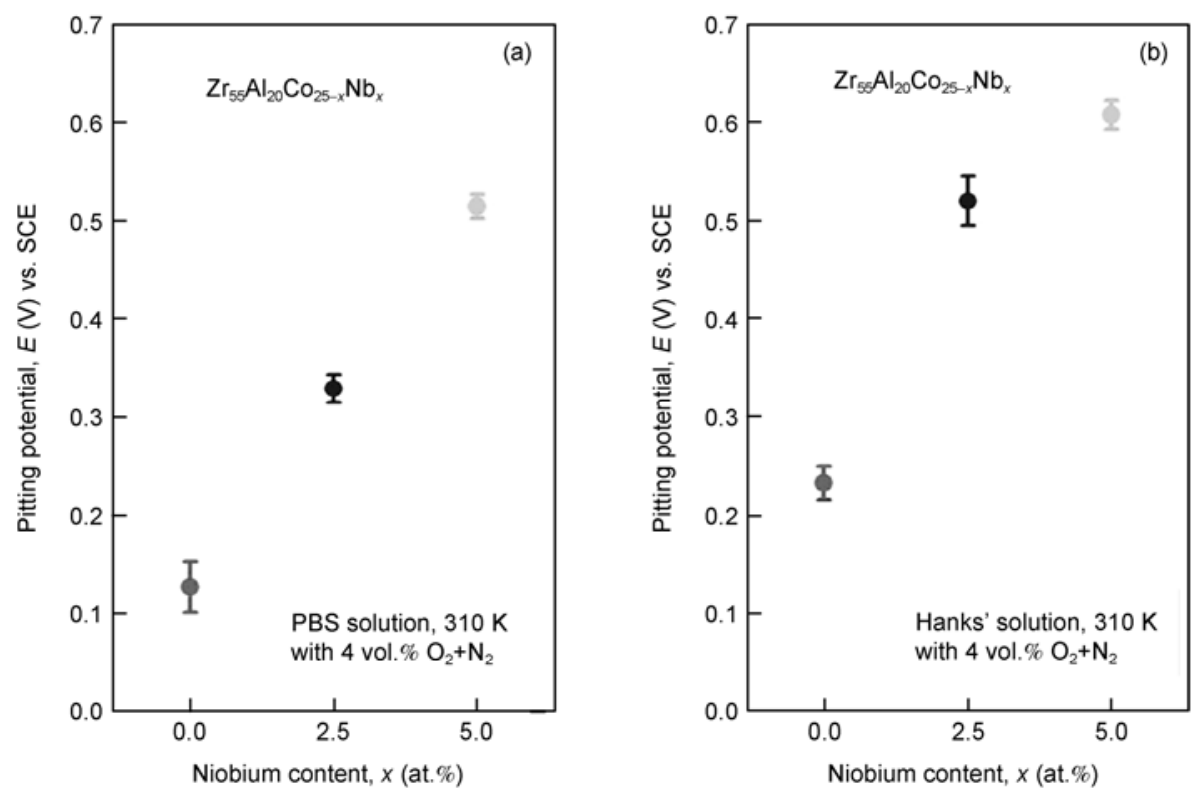

Figure 5 Changes in the pitting potentials of $\mathrm{Zr}_{55} \mathrm{Al}_{20} \mathrm{Co}_{25-x} \mathrm{Nb}_{x}(x=0,2.5$ at.\% and 5 at.\%) glassy alloys with $\mathrm{Nb}$ content in PBS and Hanks' solution.

fluids. The positive effect on the corrosion resistance of the $\mathrm{Zr}$-Al-Co glassy alloy by $\mathrm{Nb}$ addition can be attributed to the change in the composition of the passive film. It has been reported that $\mathrm{Nb}$ addition contributes to the formation of a protective surface film with higher chemical stability [20].

Water contact angle results for the $\mathrm{Zr}-\mathrm{Al}-\mathrm{Co}-\mathrm{Nb}$ glassy alloys are presented in Figure 6. The same abrasion procedure diminishes the effect of surface roughness on the surface wettability. The water contact angle decreases considerably with the addition of $\mathrm{Nb}$, which indicates higher hydrophilicity of the $\mathrm{Nb}$-containing alloys. When the $\mathrm{Nb}$ content reaches 5 at.\%, the water contact angles become smaller than the Berg limit $\left(\theta=65^{\circ}\right)$, which is beneficial for biomedical applications [26]. The present experimental results indicate that $\mathrm{Nb}$ addition simultaneously improves both the hydrophilicity and the corrosion resistance of the $\mathrm{Zr}$-Al-Co$\mathrm{Nb}$ glassy alloys. This is different from an earlier finding that related high corrosion resistance with low hydrophilicity for $\mathrm{ZrTiCuNiBe}$ metallic glasses [27]. The improvement in the corrosion resistance of the $\mathrm{Zr}$-Al-Co glassy alloy with $\mathrm{Nb}$ addition is attributed to the change in the composition of the passive film, because $\mathrm{Nb}$ addition to Zr-based glassy alloys induces the formation of a more protective passive film enriched in $\mathrm{Nb}$ [20]. Further research will be carried out to clarify whether the composition or wettability is dominant in determining the corrosion resistance of various glassy alloy systems.

\section{Conclusions}

Ni- and $\mathrm{Cu}$-free $\mathrm{Zr}_{55} \mathrm{Al}_{20} \mathrm{Co}_{25-} \mathrm{Nb}_{x}(x=2.5$ at.\% and 5 at.\%)

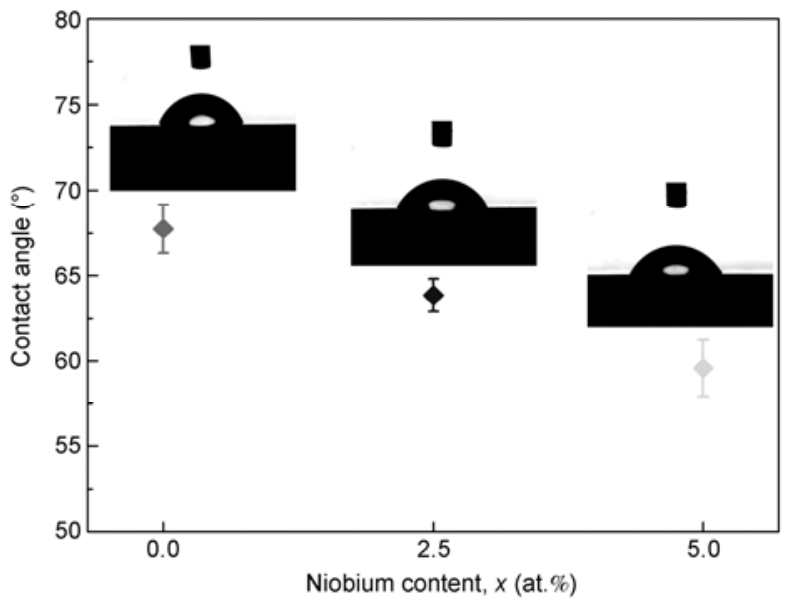

Figure 6 Contact angles of water droplets measured on $\mathrm{Zr}_{55} \mathrm{Al}_{20} \mathrm{Co}_{25-x} \mathrm{Nb}_{x}$ $(x=0,2.5$ at. $\%$ and 5 at.\%) glassy alloys.

BMGs with critical diameters up to $3 \mathrm{~mm}$ were developed. The glassy alloys exhibited high thermal stability, and good biocorrosion resistance and surface wettability. $\mathrm{Nb}$ addition was slightly detrimental to the GFA. The corrosion resistance of the Zr-Al-Co BMG in PBS and Hanks' solution was improved considerably with the increase in $\mathrm{Nb}$ content, which was indicated by the widening of the passive region, and the increases in pitting potential and OCP. Water contact angle measurements showed that $\mathrm{Nb}$ addition improved the hydrophilicity of the alloy, which is beneficial for biomedical applications.

This work was supported by the National Natural Science Foundation of China (51161130526 and 50771005) and the Innovation Foundation of Beihang University (BUAA) for PhD Graduates (special program for DSAE). 
1 Johnson W L. Bulk glass-forming metallic alloys: Science and technology. MRS Bull, 1999, 24: 42-56

2 Wang W H, Dong C, Shek C H. Bulk metallic glasses. Mater Sci Eng: R: Reports, 2004, 44: 45-89

3 Greer A L, Ma E. Bulk metallic glasses: At the cutting edge of metals research. MRS Bull, 2007, 32: 611-619

4 Ma M Z, Liu R P, Xiao Y, et al. Wear resistance of Zr-based bulk metallic glass applied in bearing rollers. Mater Sci Eng: A, 2004, 386: 326-330

5 Inoue A. Bulk Amorphous Alloys: Practical Characteristics and Applications. Switzerland: Trans Tech Publications Ltd, 1999

6 Yamamoto A, Honma R, Sumita M. Cytotoxicity evaluation of 43 metal salts using murine fibroblasts and osteoblastic cells. J Biom Mater Res, 1998, 39: 331-340

7 Inoue A, Kawase D, Tsai A P, et al. Stability and transformation to crystalline phases of amorphous $\mathrm{Zr}-\mathrm{Al}-\mathrm{Cu}$ alloys with significant supercooled liquid region. Mater Sci Eng: A, 1994, 178: 255-263

8 Wada T, Zhang T, Inoue A. Formation, thermal stability and mechanical properties in Zr-Al-Co bulk glassy alloys. Mater Trans-JIM, 2002, 43: 2843-2846

9 Zhang T, Inoue A. New glassy Zr-Al-Fe and Zr-Al-Co alloys with a large supercooled liquid region. Mater Trans-JIM, 2002, 43: 267-270

10 Zhang T, Inoue A. Formation, thermal and mechanical properties of bulk glassy alloys in $\mathrm{Zr}-\mathrm{Al}-\mathrm{Co}$ and $\mathrm{Zr}-\mathrm{Al}-\mathrm{Co}-\mathrm{Cu}$ systems. Mater Sci Eng: A, 2004, 375: 432-435

11 Wada T, Qin F X, Wang X M, et al. Formation and bioactivation of Zr-Al-Co bulk metallic glasses. J Mater Res, 2009, 24: 2941-2948

12 Wada T, Zhang T, Inoue A. Formation and high mechanical strength of bulk glassy alloys in Zr-Al-Co-Cu system. Mater Trans-JIM, 2003, 44: 1839-1844

13 Jin $\mathrm{K} \mathrm{F}$, Löffler J F. Bulk metallic glass formation in $\mathrm{Zr}-\mathrm{Cu}-\mathrm{Fe}-\mathrm{Al}$ alloys. Appl Phys Lett, 2005, 86: 241909

14 Qiu C L, Chen Q, Liu L, et al. A novel Ni-free Zr-based bulk metallic glass with enhanced plasticity and good biocompatibility. Script Mater, 2006, 55: 605-608
15 Jiang Q K, Wang X D, Nie X P, et al. Zr-(Cu,Ag)-Al bulk metallic glasses. Acta Mater, 2008, 56: 1785-1796

16 Liu L, Qiu C L, Huang C Y, et al. Biocompatibility of Ni-free Zrbased bulk metallic glasses. Intermetallics, 2009, 17: 235-240

17 Zhang C, Li N, Pan J, et al. Enhancement of glass-forming ability and bio-corrosion resistance of $\mathrm{Zr}-\mathrm{Co}-\mathrm{Al}$ bulk metallic glasses by the addition of Ag. J Alloys Compounds, 2010, 50: S163-S167

18 Hua N B, Pang S J, Li Y, et al. Ni- and Cu-free Zr-Al-Co-Ag bulk metallic glasses with superior glass-forming ability. J Mater Res, 2011, 26: 539-546

19 Buzzi S, Jin K, Uggowitzer P J, et al. Cytotoxicity of Zr-based bulk metallic glasses. Intermetallics, 2006, 14: 729-734

20 Pang S J, Zhang T, Asami K, et al. Formation, corrosion behavior, and mechanical properties of bulk glassy $\mathrm{Zr}$-Al-Co-Nb alloys. J Mater Res, 2003, 18: 1652-1658

21 Niinomi M. Recent metallic materials for biomedical applications. Metal Mater Trans A, 2002, 33: 477-486

22 Catelas I, Petit A, Zukor D J, et al. Cytotoxic and apoptotic effects of cobalt and chromium ions on $\mathrm{J} 774$ macrophages-Implication of caspase-3 in the apoptotic pathway. J Mater Sci: Mater Med, 2001, 12: 949-953

23 Nordberg G F, Fowler B A, Nordberg M, et al. Handbook on the Toxicology of Metals, 3rd ed. Amsterdam: Elsevier, 2007

24 Ponsonnet L, Reybier K, Jaffrezic N, et al. Relationship between surface properties (roughness, wettability) of titanium and titanium alloys and cell behaviour. Mater Sci Eng: C, 2003, 23: 551-560

25 Ochsenbein A, Chai F, Winter S, et al. Osteoblast responses to different oxide coatings produced by the sol-gel process on titanium substrates. Acta Biomater, 2008, 4: 1506-1517

26 Vogler E A. Structure and reactivity of water at biomaterial surfaces. Adv Colloid Interface Sci, 1998, 74: 69-117

27 Wang Y B, Li H F, Zheng Y F, et al. Correlation between corrosion performance and surface wettability in $\mathrm{ZrTiCuNiBe}$ bulk metallic glasses. Appl Phys Lett, 2010, 96: 251909

Open Access This article is distributed under the terms of the Creative Commons Attribution License which permits any use, distribution, and reproduction in any medium, provided the original author(s) and source are credited. 